\title{
VOYOTSESHCHYKANDRIY,
}

PhD in Economic Science, Associate Professor, Head of the Department of Specialized Training, Director of the Department of Specialized Training and Cynological Support of DFS, Khmelnytskyi

\section{IDENTIFICATION OF CHEMICAL AND EXPLOSIVE GOODS WHILETRANSFERRING THROUGH CUSTOMS BORDER: GLOBAL THREATS AND CHALLENGES FOR COUNTRIES}

\begin{abstract}
The article substantiates the dangers of illegal chemical and explosive goods transferring between countries. The threats arising from the use of chemical precursors for the production of homemade explosive weapons, including terrorist organizations, have been argued. The role of the World Customs Organization in counteracting the illegal transferring of chemical precursors across the border is analyzed. The features of the Global Shield program are revealed in counteracting the risks of customs space while transferring chemical precursors. The problems that exist when moving chemical precursors across the customs border of Ukraine are determined.
\end{abstract}

Key words: customs security; World Customs Organization; customs risks; illegal transferring of goods; Global Shield program; homemade explosive devices; chemical precursors.

Problem tsatement. Issues of the security of the customs space extend beyond the the national boundaries gainingglobal character and uniting the efforts of the world community to solve them, in particular, reducing the negative impact on the socio-economic and environmental spheresfor the countries development,transferring of dangerous goods and items. For decades, the countries did not realize the danger for the human life caused by scientific and technological progress and the latest developments. That is why industrial and post-industrial economies, based on innovative development, have brought not only positive changes, but also new challenges that create favorable conditions for worsening global conflicts, destroying the environment, developing terrorism and increasing military tension. Recently, the issue of illegal transferring of dangerous goods through the customs border,in particular so-called "chemical precursors"are being actualized.As they have negative environmental consequences and can be used for the creating of homemade explosive devices, and therefore present a direct threat for the security of the countries.

Anlysis of research and publications. Such scientists as, I. Berezhnyuk, A. Kalinichenko, K. Krisovat, V. Martyniuk, K. Novikov, P. Pashko and others, devoted their works to the study of economic, legal, and social aspects of security of countries while transferring goods through customs borders. [1-6]. At the same time, the issue of emerging risks for the customs (both national and global) during illegal circulation and transferring chemicals and explosive goods across the customs borders is being actualized. However, this aspect is practically unexplored in the scientific literature.

The purpose of the article is to justify the danger of illegal transferring and identification of chemical and explosive goods between countries, assessment of the "Global Shield Program" as a mechanism for global counteraction to the threats posed by the transferring such goods across the customs border, peculiarities of overcoming risks while transferring chemical precursors across the Ukrainian customs border.
Presentation of main material. The growing globalization and liberalization of the conditions for the transferring goods, the simultaneous expansion of trade and crime, the growing threat of terrorist acts, the introduction of information systems for improving the state of national security (including customs) and the fight against fraud are far from being a complete list of issues that are needed to be solved in order to create safe and favorable supply chains in accordance with the WMO Framework.

The threats to the lives and health of the population in the era of global change are exacerbated by increased terrorist challenges to national security of countries, the growth of military conflicts, the opening of customs borders and the spread of weapons, primarily explosive one. Every year, the Action on Armed Violence (AOAV) publishes a study on the assessment of the risks of using explosive weapons in the world. So according to the 2016 report (which was one of the worst by indicators since the 2011 survey), the following information was found out: in 2016, it was recorded 45,624 deaths and injuries from the use of explosive weapons, and the most suffered the civilian population - $32088(70,3 \%)$ cases; in 2016 , as compared to 2011 , an increase of $92 \%$ in the number of dead (civilians) from explosive weapons occurred (by $5 \%$ compared to 2015). Syria (51\% increase over 2015), Iraq, Yemen, Afghanistan and Turkey $(113 \%$ increase) led the number of deaths and injuries among the civilian population as a result of the use of explosive weapons [7].

Therefore, at the time of taking collective responsibility not only for the illegal transferring explosive weapons, but also chemical precursors that are used for its creation. The use of chemical precursors for creation of homemade explosive devices, simplifies in great way the mechanism of their transferring through customs borders, as requirements for its transferring are not such strict as to the transferrin weapons and explosive devices. Therefore, resolving the problems of customs control by countries itself is impossible and objectively demands involving international organizations, in particular, the World Customs Organization in order to solve these problems. 


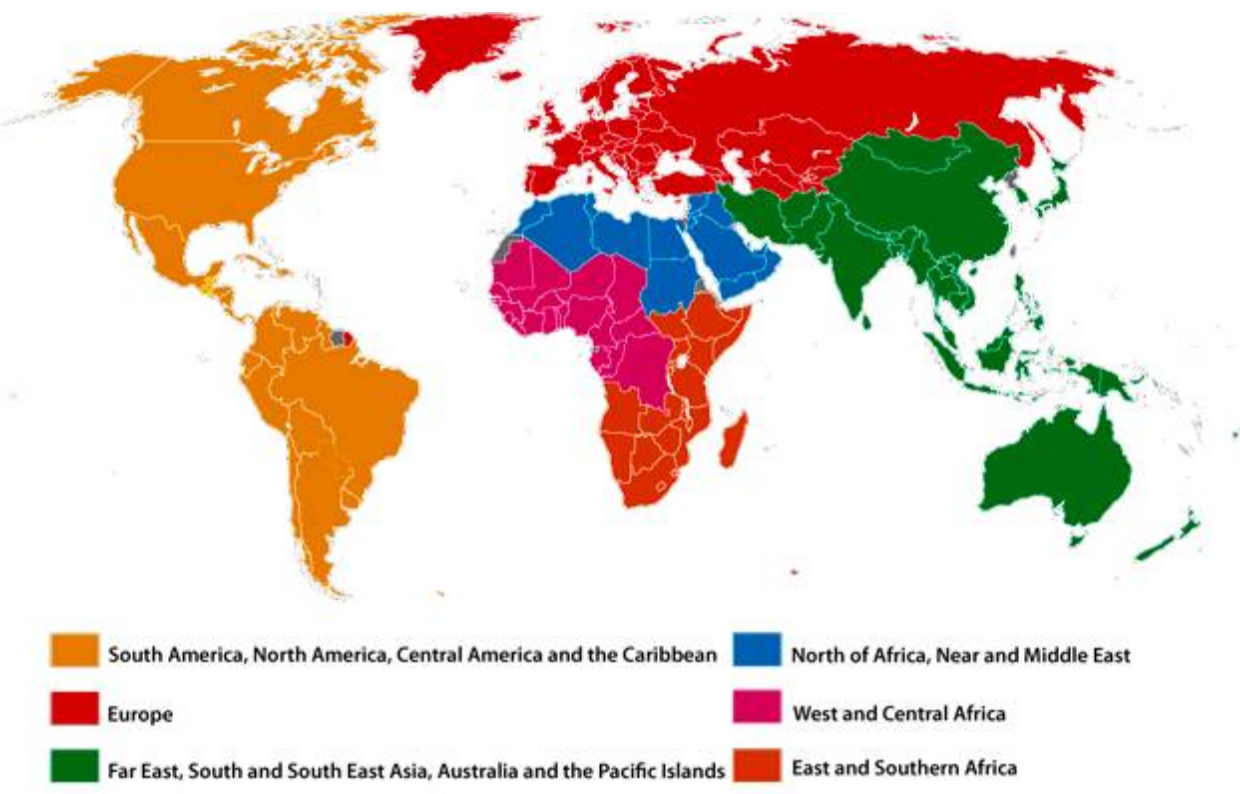

Pic. 1. Map of member countries of the World Customs Organization.

The initiatives of the World Customs Organization to $\mathrm{c}$ counteract the illegal transferring goods are very effective as for today WMO includes 182 countries (Figure 1), which account for $98 \%$ of world trade.

WMO focuses on the use of advanced technologies to detect the illegal transferring of goods, the application of innovative approaches to risk management and the implementation of recommendations of the organization in the practice of customs, the improvement of personnel policies, conducting training seminars and trainings about modern ways of the illegal transferring goods and the acquiring skills for their detection and prevention, the establishment of partnerships between countries in the process of carrying out customs control.Among the main WMO activities are the detection of illegal chains of supply of chemical precursors. The Global Shield program was launched in 2010 to counteract the illegal transferring of so-called "chemical precursors" through the customs border. The threat of their transferring is not only for people and the environment in the terms of the danger they possess during illegal transferring, but also in the context of their further use. After all, chemicals can have dual purpose, in particular, used for the creation of homemade explosive devices, so the circulation of chemicals is controlled by international criminal groups, including terrorist ones. The main directions of the Program were declared: education; law enforcement operations; cooperation; technical support (development of identification tools). The Strategic Plan of the Program covered four levels: institutional development; Global Shield military operations; information support and intelligence; estimation and forecasting.

The Global Shield program primarily monitors the following explosive chemical substances: ammonium nitrate (ammonium nitrate) (NH4NO3); nitromethane $(\mathrm{CH} 3-$ $\mathrm{NO} 2$ ); sodium nitrate (NaNO3); Potassium Nitrate (KNO3); sodium chlorate $(\mathrm{NaClO} 3)$; potassium chlorate $(\mathrm{KClO} 3)$; potassium perchlorate $(\mathrm{KClO} 4)$; acetone $(\mathrm{C} 3 \mathrm{H} 6 \mathrm{O})$; hydrogen peroxide ( $\mathrm{H} 2 \mathrm{O} 2)$; nitric acid (HNO3); urea (carbamide) (CH4N2O); aluminum powder; ammonium nitrate calcium (Ca (NO3) 2); acetic anhydride ((CH3CO) 2 O). Illegal transferring and the use of these chemicals are a threat to people's lives and health. Since 2015 , the program has taken control and displacement of detonators.

Since the beginning of the Global Shield program, operations have been carried out to remove chemical precursors (Figure 2). Thus, in 2015, the Program eliminated $543818 \mathrm{~kg}$ of solid precursors and 33360 liters of liquid precursors.

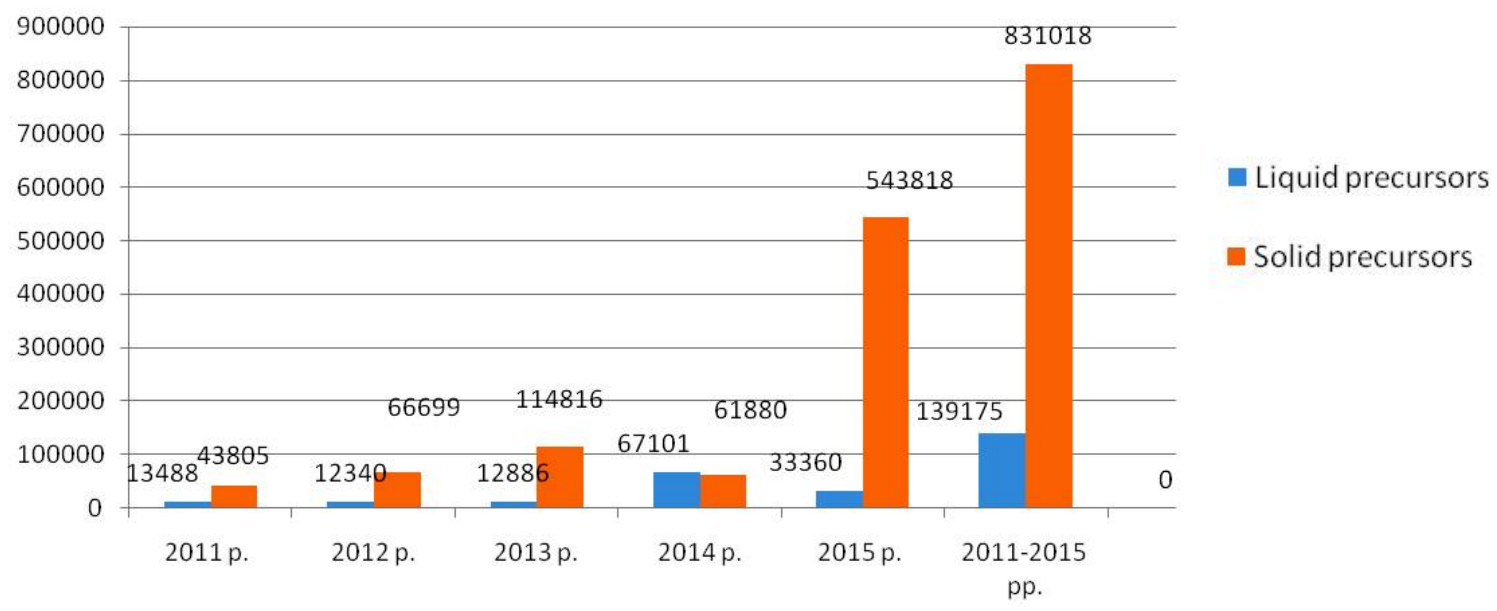

Fig. 2. Dynamics of chemical precursor extraction under the "Global Shield Program" [8, P. 135].

\section{СХІД № 4 (150) липень-серпень 2017 р.}


Among chemical precursors, ammonium nitrate is most often used by terrorist organizations and countries (in particular ISIL for the creation of explosive devices. At the same time, according to study conducted by the organization "Conflict Armament Research" Mostly,Turkish and Iraqi companies were involved in the supply chain of chemical components for the creation of explosives during the period July 2014 - February 2016, Iraq [9]: 50 commercial structures from 20 countries are involved in these processes. Companies that have supplied chemical precursors to ISIL are listed in Table. 1.

That is, global threats force the countries should imple-

Table 1. - Countries and companies supplying chemical precursors to ISIL forces for the creating explosive devices [9]

\begin{tabular}{|c|c|c|}
\hline Type of material & Company & Country \\
\hline Chemical precursors & Aldoro & Brazil \\
\hline Chemical precursors & G?Ita? Kimya & Turkey \\
\hline Chemical precursors & Alba Aluminiu & Romania \\
\hline Chemical precursors & 3D Lojistik & Turkey \\
\hline Chemical precursors & $\begin{array}{l}\text { Marikem Kimyevi ve } \\
\text { End?striyel ?r?nler }\end{array}$ & Turkey \\
\hline Chemical precursors & Sunrise Aluminium Pigments & China \\
\hline Chemical precursors & Metkim & Turkey \\
\hline Chemical precursors & Unknown & Russia \\
\hline Chemical precursors & Mert Global & Turkey \\
\hline Chemical precursors & EKM G?bre & Turkey \\
\hline Containers/Chemical precursors & Solvay Chemicals International & Belgium (headquarters) \\
\hline Containers/ Chemical precursors & Solvay Chemie & Netherlands \\
\hline Containers/Chemical precursors & Diversey Kimya & Turkey \\
\hline Containers/Chemical precursors & Diversey Gulf & UAE \\
\hline Containers/Chemical precursors & $\begin{array}{l}\text { Mazen Khanati Serrieh Trading \& } \\
\text { Distributing }\end{array}$ & Iraq \\
\hline Containers/ Chemical precursors & Karwanchi Group & Iraq \\
\hline Containers/Chemical precursors & Al Safi Danone & Iraq \\
\hline Containers/Chemical precursors & Ehsan Chemi Company & Iran \\
\hline Manufacturer & Mediator & Declarant and consumer \\
\hline
\end{tabular}

ment measures to protect the national customs space from international illegal supply chains of chemical precursors, first of all, for the needs of terrorist organizations. World practice confirms that the customs business develops through the implementation of such instrument as a risk management system in the process of the customs control and customs clearance. The functioning peculiarity of the risk management system is that it provides focusing the attention of customs officials not only on the control of the completeness and timeliness of tax revenues to the budget, but also on the identification of non-fiscal risks associated with threats to national security, life and health of people, the environment, the interests of consumers. The mentioned system allows to identify the general flow of exactly those passengers and goods which transferring is associated with the greatest risk of non-compliance with customs legislation. The available resources (both human and technical) are aimed at providing the deepest control of the most risky transactions. As a result, other goods and passengers move trough the country's customs border by the green corridor or they face with minimum control procedures.

Chemicals are an example of goods are characterized by non-fiscal risks while transferring though the customs border, because there is a danger of their use for creating homemade explosive devices. To detect chemical products among the general flow of goods is a simple task, especially if it is possible to inspect surface of the vehicle as such products are usually displaced in special conditions due to their physical and chemical properties or conditions of use.Therefore, in this case, the security of the customs space depends on the professionalism of the inspection procedure. So, when transferring chemicals through the customs border, it is important to identify the contents of the goods, because they have a specific classification, labeling and packaging.
Preventive pictograms on the product provide basic information about the possible danger of the cargo (Fig. 3).

Along with warning icons, transportation icons are used. In accordance with the requirements for the labeling containers and packaging, it is necessary to specify: the name of the transported chemical substance; the inscription - DANGER or WARNING (depending on the degree of danger); warning marking; information about the vendor. Depending on the degree of danger of chemical substances being transported, the following containers can be used: barrels / buckets, barrels, canisters, boxes, bags, combined packaging. It is allowed to put on the product additional information about manufacturer, graphic information. On the means of transportation, it is mandatory to designate warning signs about the dangers of the load (for example, fig. 4).

Concerning the safe transportation of dangerous goods, the UN has developed mechanisms for harmonizing the criteria for hazard classification and transport conditions by various modes of transport [10], in 2003 it approved a system for hazard classification and labeling of chemical products [11] (Figure 5).

Therefore, customs officers should have sufficient information about chemical precursors and verify their correct classification: by the HS (Harmonized System), fourdigit UN number [12], CAS (Chemical Abstract Service) [13]. The classification codes for individual chemical precursors are given in Table. 2.

During the last decade, the approach to the functional tasks of customs is changing. Ukraine is also involved in this process. If previously the implementation of fiscal functions was in priority by the customs as well as ensuring the implementation of planned targets for tax revenues and fees to the budget but now more important is protection of citizens and their interests, reduction of threats to national security, promotion of legitimate trade. For Ukraine, 


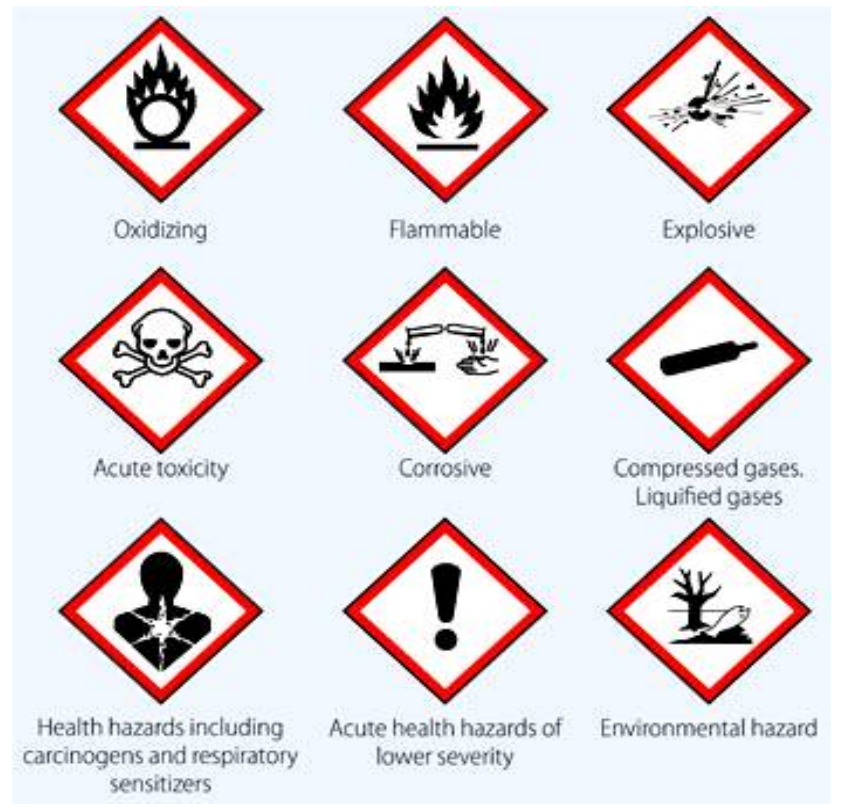

Fig. 3. Warning icons about cargo danger (compiled from Global Shield, WCO)

\section{UN System}

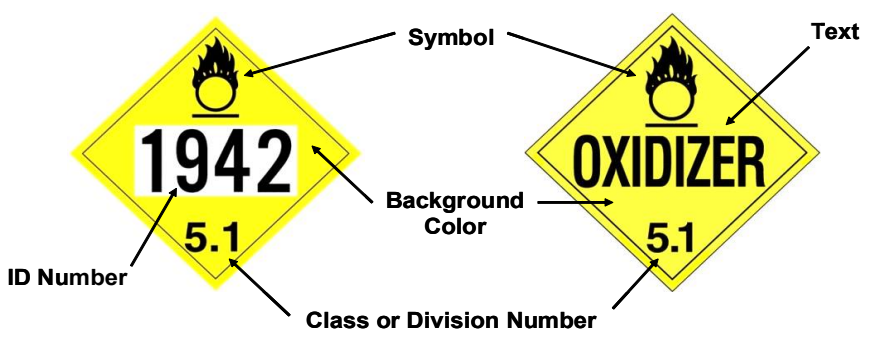

Fig. 4. Warning signs for the goods being transported (prepared by Global Shield (WCO))

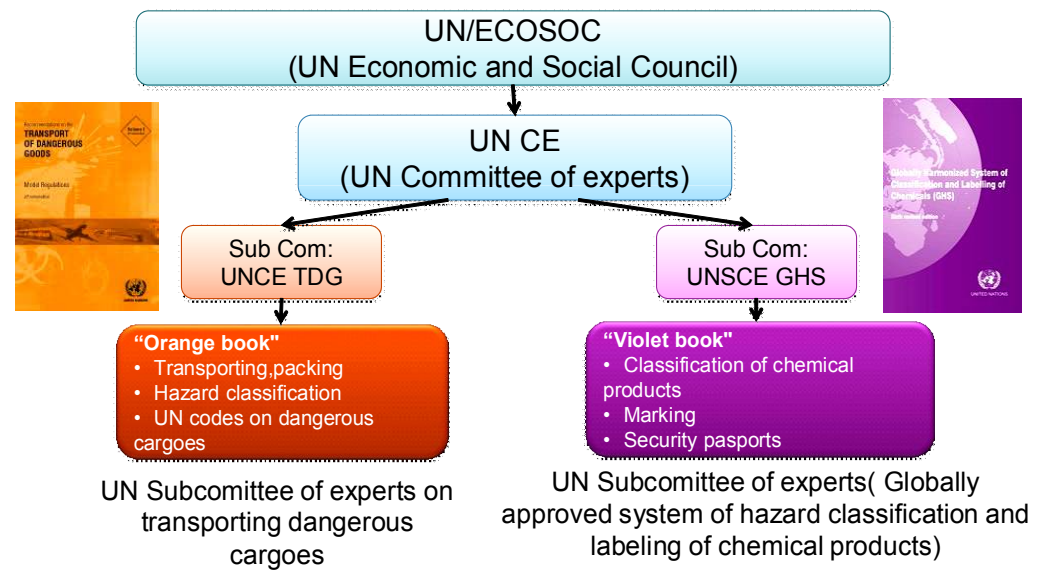

Fig. 5. The role of the UN in the regulation of the transferring dangerous goods (compiled on the basis of Global Shield (WCO) materials)

these issues become ongoing too due to the openness of the eastern borders of the country and the lack of proper control of transferring goods and items .During the inspection and control procedures conducted by customs service, there is a risk that the part of such goods will not be added to controlled lists. Accordingly, the main task for a customs officer, who controls the transferring of chemicals, is the necessity to ensure that the goods submitted to customs control correspond to the specified shipping documents. This can be verified by verifying or denying by the available information. That is, to verify that this product was declared, it is necessary to check all its characteristics with real ones and receive positive answers, or to identify differences in key positions in order to have grounds for concluding that this product does not exactly correspond to the declared ones. Employees of the surveyed customs 
Table 2. - Coding of certain chemical precursors substances

\begin{tabular}{|l|c|c|c|}
\hline Name of chemical precursor & Code HS & Code CAS & Number OOH \\
\hline Ammonium nitrate & 310230 & $6484-52-2$ & 1942 \\
\hline Nitrometean & 290420 & $75-52-5$ & 1261 \\
\hline Sodium nitrate & 310250 & $7631-99-4$ & 1498 \\
\hline Potassium nitrate & 283421 & $7757-79-1$ & 1486 \\
\hline Sodium chlorate & 282911 & $7775-09-9$ & 1495 \\
\hline Sodium chlorate & 280800 & $7697-37-2,43625-06-5,13587-52-5$ & $1796 ; 1826 ; 2031 ; 2032$ \\
\hline
\end{tabular}

should be able to analyze the information in chemical security certificate in order to identify the possible risks, as at the border there may be cases of violation of the integrity of the packaging and other dangers. It is necessary to identify the product (name, manufacturer, location, contact person in the case of an emergency), information about chemical status of the product and its toxicity, information about the effect of the product on a person, signs of exposure and first aid, flammable and chemical activity, measures, which should be introduced while violation of the security of the chemical product, precautions, requirements for personal protective equipment, physical and mimic properties of the product.

As a rule, visual checking of goods does not cope with all dubious situations and for conducting additional measures, in particular for sampling, it is necessary to identify signs that would witness the threat of violation of customs legislation. To do this, it is necessary to analyze the potential risks starting from studying the documents submitted to customs control; studying affaires of entities involved in this transaction of goods. In order to figure out if this supply is typical for their business, as well as the transferring of goods itself, its way of transferring, the possibility of concealing the destination / departure, etc. Taking into account the dual use of chemical precursors, there is a danger of improper use of them after crossing the customs border. For example, ammonium nitrate is used as nitrogen fertilizer; nitromethane is used to make pills, pesticides are used as an industrial solvent; sodium nitrate is used as a preservative for meat and fish products as anticorrosive substance; chlorate of sodium and potassium are used as herbicides and defoliants; Nitric acid is used as fertilizer,etc. Thus, taking into account the danger of using chemical precursors while making homemade explosive devices which may entail, it is necessary to strengthen the control over their transferring through the customs border and to track transferring through the country's territory and its intended use.

The analysis of detected violations of customs legislation during the transferring such chemicals through customs border indicates that they are committed either carelessly or deliberately. Thus, in the first case, the person due to his ignorance of the legislation does not have information about the necessity of obtaining permits, or they do not inform the final consumer about the actual purpose of these goods, their characteristics and the potential threats that they can bear.

While committing a violation in a deliberate way, offenders use all the capabilities available to them to avoid proper customs control of the goods, starting with the adding false information to the shipping documents or failing to indicate important characteristics in general; they use documents issued for other goods, or receive permits on the basis of false documents, change markings on goods and their packaging, ignore the requirements for the application of precautionary measures, etc.

The Global Shield program has launched a new ap- proach to control the transfer of chemicals that can be used for making homemade explosive devices. This initiative was also supported by the EU countries and EU Directive No. 552/2009 on the use of ammonium nitrate for the creating of explosives was adopted; in 2008 the European Parliament decided to restrict the use of chemicals, including ammonium nitrate. Ukraine, positioning itself as a state supporting the idea of security in the world, should adapt national legislation and implement the practice of legal regulation of the transferring through the customs border and the further circulation of chemicals that can be used for creation of homemade explosive devices. In May 2017, on the basis of the State Fiscal Service of Ukraine, thematic seminars on implementation of the Global Shield program and the provision of trainer support to customs officials were launched [14].

\section{Conclusions}

1. Due to the growing global challenges and terrorist threats, the issue of the transferring chemical and explosive goods and the creation of controlled supply chains needs to be resolved. Such problem is of a current interest not only for Ukraine but also for the whole world. In order to counteract their illegal distribution, international organizations, such as World Customs Organization develop specialized programs and tools to spread information among customs officials. It concerns the identification of chemical substances used for the creation of explosives, in particular their marking, methods of concealment and illegal transferring as well as the procedure of using such substances in order to minimize the health and life threatening for customs officers who perform customs formalities and procedures.

2. The Global Shield program is one of the real mechanisms for responding to the global threats posed by the displacement of chemical precursors. The implementation of a risk management system, including Ukraine, allows partially to control transferring such goods through the customs border of the country.

For carrying carry out an effective customs inspection of goods at crossing the Ukrainian customs border in accordance with the objectives of the Global Shield program, the issue of ensuring customs clearance by technical and human resources during the control of the movement of each unit of a good, container or vehicle is unresolved and demands conducting trainings for customs officers who will responsible for the inspection of chemical products and accompanying documents and is one of the main steps of the implementation of the Global Shield Program in Ukraine.

3. In order to ensure the security of the customs territory, we consider it necessary to develop and implement with the law-enforcement and controlling bodies of Ukraine the National Control Program of the production, circulation, usage, identification, transportation, transferring of chemical, biological, radiological, nuclear, explosive goods through the customs border of the country. This approach 
will enable Ukraine to actively integrate into the processes of detecting and counteracting illegal supply chains of chemical precursors according to the standarts of WMO and Global Shield Program.

\section{REFERENCES}

1. Berezhnyuk, I. G., etc. (2014), Risk management in customs: foreign experience and domestic practice, State Research Institute of Customs Affairs; Melnyk A.A. Publisher, Khmelnitsky, 287 p. (ukr).

2. Kalinichenko, A. I. (2015), Customs safety as a component of national security of Ukraine, Pravo ta innovatsii, № 2; 14-18 (ukr).

3. Krysovata, K.V. (2012), The world experience in managing financial risks and the possibility of its implementation in the customs territory of Ukraine, Economic Journal - XXI. No. 11-12, p. 58-61 (ukr).

4. Martyniuk, V.P. (2010), Customs system and economic security of the state: theory and methodology, Aston Publishing, Ternopil, 256 p. (ukr).

5. Novikova, K. I. (2012), Globalization Challenges to the Customs Security of the State, Bulletin of the Zaporizhzhya National University, No. 4 (16), pp. 174-180 (ukr).

6. Pashko, P.V. \& Berezhnyuk, I.G. \& Hrebelnyk, O.P. and others (2012), Customs policy and customs security: conceptual definition and ways of securing, Znannia, Kyiv, 215 p. (ukr).

7. Explosive truths: Monitoring explosive violence in 2016, available at: https://aoav.org.uk/2017/explosive-truths-monitoringexplosive-violence-2016/

8. Illicit Trade Report 2015. WCO, available at: https:// illicittrade.com/reports/downloads/OMD_ITR_Complete_LR_2016 _12_04.pdf

9. Tracing the supply of components used in Islamic State IEDs. Published online by Conflict Armament Research, London, 2016, available at: http://www.conflictarm.com/wp-content/ uploads/2016/02/Tracing_The_Supply_of_Components_Used in_Islamic_State_IEDs.pdf

10. Dangerous Goods, available at: http://www.unece.org/ trans/danger/danger.html

11. The Globally Harmonized System of Classification and Labelling of Chemicals (GHS), available at: https:// www.unece.org/fileadmin/DAM/trans/.../ghs/ghs.../ST-SG-AC1030-Rev4e.pdf

12. Dangerous goods list and limited quantities exceptions, available at: https://www.unece.org/fileadmin/DAM/trans/danger/ publi/unrec/.../03E_Part3.pdf

13. CAS Registry and CAS Registry Number FAQs, available at: https://www.cas.org/content/chemical-substances/faqs

14. Customs officers from all over Ukraine took part in the Global Shield (Global Shield) workshop of the World Customs Organization aimed at combating the illegal movement of so-called "chemical precursors», available at: http://sfs.gov.ua/pro-sfsukraini/struktura-/aparat/departament-organizatsii-mitnogo-kont/ povidomlennya/252067.html

Войцещук Андрей,

кандидат экономических наук, доцент, директор

Департамента специилизированной подготовки и кинологического обеспечения ГФС, г. Хмельницкий

\section{ИДЕНТИФИКАЦИЯ ХИМИЧЕСКИХ И ВЗРЫВООПАСНЫХ ТОВАРОВ ПРИ ПЕРЕМЕЩЕНИИ ЧЕРЕЗ ТАМОЖЕННУЮ ГРАНИЦУ: ГЛОБАЛЬНЫЕ УГРОЗЫ И ВЫЗОВЫ ДЛЯ СТРАН}

В статье обоснованы опасности незаконного перемещения химических и взрывоопасных товаров между странами. Аргументированы угрозы, возникающие при использовании химических прекурсоров для производства самодельного взрывчатого оружия, в том числе и террористическими организациями. Проанализирована роль Всемирной таможенной организации в противодействии незаконному перемещению через границу химических прекурсоров. Показано, что одним из реальных механизмов противодействия глобальным угрозам, возникающим при перемещении химических прекурсоров, является программа "Глобальный щит", реализуемая в целях борьбы с незаконным перемещением через таможенную границу так называемых "химических прекурсоров". Для обеспечения безопасности таможенного пространства предложено практическое внедрение совместной с правоохранительными и контролирующими органами Украины Национальной программы контроля за производством, оборотом, использованием, идентификацией, транспортировкой, перемещением через таможенную границу страны химических, биологических, радиологических, ядерных, взрывоопасных продуктов. По мнению автора, такой подход позволит Украине активно интегрироваться в процессы выявления и противодействия незаконным цепям поставок химических прекурсоров с учетом рамочных стандартов ВТО и Программы "Глобальный щит".

Ключевые слова: безопасность таможенного пространства; Всемирная таможенная организация; таможенные риски; незаконное перемещение товаров; Программа "Глобальный щит"; самодельные взрывные устройства; химические прекурсоры.

Войцещук Андрій, кандидат економічних наук, доцент, директор

Департаменту спеціалізованої підготовки та кінологічного забезпечення ДФС, м. Хмельницький

\section{ІДЕНТИФІКАЦІЯ ХІМІЧНИХ ТА ВИБУХОНЕБЕЗПЕЧНИХ ТОВАРІВ ПРИ ПЕРЕМІЩЕННІ ЧЕРЕЗ МИТНИЙ КОРДОН: ГЛОБАЛЬНІ ЗАГРОЗИ ТА ВИКЛИКИ ДЛЯ КРАЇН}

У статті обґрунтовано небезпеки незаконного переміщення хімічних та вибухонебезпечних товарів між країнами. Аргументовано загрози, що виникають при використанні хімічних прекурсорів для виробництва саморобної вибухової зброї, в тому числі й терористичними організаціями. Проаналізовано роль Всесвітньої митної

СХІД № 4 (150) липень-серпень 2017 р. 
організації у протидії незаконному переміщенню через кордон хімічних прекурсорів. Показано, що одним із реальних механізмів протидії глобальним загрозам, що виникають при переміщенні хімічних прекурсорів, $\epsilon$ програма "Глобальний щит", що реалізується з метою боротьби із незаконним переміщенням через митний кордон так званих "хімічних прекурсорів". Для забезпечення безпеки митного простору запропоновано практичне впровадження спільної із правоохоронними та контролюючими органами України Національної програми контролю за виробництвом, обігом, використання, ідентифікацією, транспортуванням, переміщенням через м итний кордон країни хімічних, біологічних, радіологічних, ядерних, вибухонебезпечних товарів. На думку автора, такий підхід дасть змогу Україні активно інтегруватися в процеси виявлення та протидії незаконним ланцюгам постачання хімічних прекурсорів з урахуванням Рамкових стандартів ВМО та Програми "Глобальний щит".

Ключові слова: безпека митного простору; Всесвітня митна організація; митні ризики; незаконне переміщення товарів; Програма "Глобальний щит"; саморобні вибухові пристрої; хімічні прекурсори.

() Войцещук Андрій

Надійшла до редакції 15.08.2017

УДК 336.3

ПІНЬ АНДРІЙ,

аспірант кафедри міжнародної економіки,

Тернопільський національний економічний університет

\title{
ЗОВНІШНЯ ЗАБОРГОВАНІСТЬ США: РИЗИКИ ТА ПРІОРИТЕТИ ФОРМУВАННЯ ЗОВНІШНЬОБОРГОВОї СТРАТЕГІЇ США
}

\begin{abstract}
У статті проаналізовано природу та структуру зовнішнього боргу Сполучених Штатів Америки та його вплив на економіку США та глобальну економіку. Показано, що накопичення зовнішнього боргу США відбувається на тлі таких тенденцій розвитку світового економічного та фрінансового середовищ, як низькі процентні ставки та повільне економічне зростання. Зазначено, що результати останніх досліджень відображають факт того, що зовнішній борг США не становить загрози світовій економіці в короткостроковій перспективі, оскільки економічне зростання світового економічного лідера перевищує темп зростання витрат, пов'язаних з обслуговуванням зовнішнього боргу. Проте в разі виникнення економічного занепаду в США, з високою ймовірністю, можуть виникнути проблеми з обслуговуванням зовнішнього боргу в довгостроковій перспективі, а отже, ризик неспроможності виконувати основні вимоги кредитних відносин, тобто вчасно здійснювати розрахунки 3 обслуговування боргів.
\end{abstract}

Ключові слова: зовнішній боре США; національний борг США; боргове фрінансування; платоспроможність та ліквідність.

Постановка проблеми. Сучасні наукові підходи до трактування природи зовнішнього боргу та його ефектів на економічні процеси опираються на факт того, що боргове фрінансування $€$ невід'ємною рисою сучасного, орієнтованого на лібералізацію, світу. Відповідно, вільні потоки капіталу між економіками $є$ ознакою тяжіння до макроекономічної рівноваги, оскільки відсутність адміністративних обмежень на розподіл капіталу сприяє вирівнюванню цін на фактори виробництва та збільшенню ефективності розподілу ресурсів. Зважаючи на ці аргументи, ціни на товари та послуги не відображають загрозливих коливань, а фрінансова система набуває стійкості та довіри з боку суб'єктів господарю- вання. Наше дослідження спирається на наявні теоретичні основи щодо природи боргу та спрямоване на аналіз зовнішнього боргу Сполучених Штатів Америки та його впливу на економіку США та глобальну економіку. Перед тим як безпосередньо перейти до дослідження власне зовнішнього боргу, необхідно висвітлити останні тенденції розвитку світового економічного та фінансового середовищ, відмітними рисами якого $€$ низькі процентні ставки та повільне економічне зростання. Міжнародний валютний фонд (МВФ) охарактеризував такі тенденції як еру "...низького зростання, низького проценту..." [3]. Разом із тим, результати останніх досліджень відображають факт того, що зовнішній 